\title{
Determinants of visitor expenditures in mountain tourism
}

\author{
PETER Fredman \\ European Tourism Research Institute (ETOUR), Mid-Sweden University, S-83125 \\ Östersund, Sweden. Tel: +46 631958 04. Fax: +46 63195810. \\ E-mail: peter.fredman@etour.se.
}

In this study, determinants of expenditures are estimated for downhill skiers, backpackers, snowmobilers and general visitors to the Swedish mountain region. The study is based on a national sample of mountain visitors. It is shown that duration of stay, household income, choice of activity, occupation, participation in an organized trip and choice of accommodation have an effect on expenditures at the destination, while gender, mode of travel, distance and 'significance of activity' are additional determinants of expenditures outside the destination. The study will contribute to our understanding of the economic values associated with the future development of mountain tourism, including values beyond primary expenditures.

Keywords: mountain tourism; expenditures; consumer surplus; downhill skiing; backpacking; snowmobiling

In many parts of the world, mountain tourism is driven by outdoor recreation activities such as downhill skiing, snowmobiling and backpacking (Weiermair et al, 1996; Buckley et al, 2000; Teigland, 2000; Hudson, 2003; Cordell, 2004), and Sweden is no exception. Heberlein et al (2002) estimated an $80 \%$ participation in downhill skiing among winter visitors to the Swedish mountain region and a $50 \%$ participation in hiking among summer visitors. Recent changes in Swedish mountain tourism show significant increases in downhill skiing and snowmobiling, while participation in more traditional activities such as backpacking and cross-country skiing has been stable or declining (Fredman and Heberlein, 2003).

With declining labour needs in mining, logging and farming, tourism has taken on a new meaning for many mountain communities, both socially and economically (Godde et al, 2000; Lundmark, 2005; Thomson et al, 2005).

This study was made possible by means of financial support from the Mountain Mistra Research Programme (Fjällmistra) and the European Tourism Research Institute (ETOUR). Valuable advice and comments from Professors Tommy D. Andersson, Lars Emmelin and Tom Heberlein, as well as two anonymous referees, during different stages of this project are acknowledged. 
While the tourism industry strives to maximize profit, political decision makers are often concerned with social welfare issues: a destination manager will seek tourists who spend money on his or her products, while the community planner will consider the range of tourists to augment local economic development. In both cases, understanding expenditure patterns and related economic values are key issues. The volume and type of non-resident visitor expenditures is the primary economic force behind regional tourism impacts and represents an influx of new money to the economy.

Studies of expenditure patterns help describe the size of each travel market in economic terms, and destinations can better benefit from marketing efforts (Regan and Damonte, 1999). It also leads to the identification of attributes influencing travel expenditure characteristics among market segments. For example, Díaz-Pérez et al (2005) segmented Canary Island tourism markets, and Mok and Iverson (2000) segmented Taiwanese visitors to Guam, based on travel expenditures. Downward and Lumsdon (2004) found that car-borne visitors to the North York Moors National Park were likely to spend more compared to public transport visitors. Suh and McAvoy (2005) showed that business travellers to Korea spent significantly more than pleasure travellers and that preference for a specific activity did not directly correlate with expenditures on the activity. In contrast, a study by Nogawa et al (1996) found that participants in Japanese sporting events differed from traditional tourists, showing that visitor expenditures were related to trip activity.

While numerous studies of household travel and expenditures are available on a macro level, less is known about individual visitor spending behaviour and the socio-economic factors that affect spending patterns (Fish and Waggle, 1996; Cannon and Ford, 2002; Mak, 2004). Previous studies have found that visitor expenditures are positively related to income (for example, Taylor et al, 1993; Lee et al, 1996; Agarwal and Yochum, 1999; Cannon and Ford, 2002; Downward and Lumsdon, 2003). Demand theory implies that as per capita incomes rise, more people are likely to travel and tourist expenditures are a positive function of income. Income is often shown to be elastic, indicating that tourism is a luxury good (for example, Lee et al, 1996).

There are, however, several factors in addition to income level that affect the demand for recreation - for example, education, age, gender, ethnicity, site quality, substitutes, travel time and congestion. Downward and Lumsdon (2000, 2003) focus on these issues in studies of visitor spending at two rural UK tourist destinations. They report the level of spending to be related to duration of stay and composition of party for day-visits, while income has a positive effect on spending behaviour for longer stay holidays. In the study by Agarwal and Yochum (1999), party size and commercial accommodation were positively related to total party expenditures. Cannon and Ford (2002) find in their study of sports events that out-of-state visitors spend more than visitors from the state in which the event takes place.

While the literature cited above exemplifies the effects of underlying demographic characteristics on visitor spending in a variety of tourism contexts, there is to my knowledge no previous study on visitor spending looking at specific tourist categories in an entire mountain region. The current study goes beyond those that measure visitor expenditures on site at a specific tourist location as it is based on a national sample of mountain visitors and considers expenditures 
both at and outside the destination. This approach makes it possible to compare the spending patterns both across the different visitor categories (that is, downhill skiers, backpackers and snowmobilers) as well as the geographical distribution of spending patterns (at and outside the mountain region). The paper also discusses values beyond out-of-pocket expenditures to broaden the enquiry to associated economic values. The subsequent sections include:

(1) a description of the study area;

(2) data collection and measurement;

(3) expenditure modelling;

(4) the study results;

(5) a discussion of values beyond primary expenditures; and

(6) concluding remarks.

\section{The study area}

For the purpose of this study, the Swedish mountain region is considered a destination unit (Figure 1). In tourism research, the destination is a frequently used concept to frame and systematize various analyses (for example, Oppermann, 2000; Klenosky, 2002; Uybers, 2003). As a notion of place, Framke (2002) argues that destinations are seen as units at several geographical levels, but without distinct geographical boundaries, and as images resulting from social practice. The Swedish mountain region has, without doubt, a special meaning to many Swedes as a 'special place' (Fredman and Heberlein, 2005). It is located in the peripheral north with vast areas of bare mountains - which is in large contrast to the forested and urbanized south where the majority of the population lives. The mountain region makes up about one third of Sweden, but includes fewer than $2 \%$ of the total population. It has 15 municipalities in four counties and features an agglomeration of specific recreational attractions (snow, cold, steepness, darkness, light, wildlife, remoteness, wilderness, etc) that cannot be found to the same extent in other parts of the country.

Although few people live permanently in the area, almost a quarter of all adult Swedes visit the mountain region in a single year (Heberlein et al, 2002). Over $85 \%$ of these visits are for recreation and leisure. The Swedish mountain region provides many opportunities for outdoor recreation, during both the winter and summer. The region stretches over $1,000 \mathrm{~km}$ in the north-west (bordering on Norway), including peaks reaching 2,000 $\mathrm{m}$ in altitude, but most of the topography is relatively gentle. Since the treeline is at a low altitude - 600-900 m above sea level - it offers easy access to areas of bare mountains suited for backpacking, cross-country skiing and snowmobiling. Skiing is usually possible from November to May, while the backpacking season lasts from mid June to September. There are about $8,000 \mathrm{~km}$ of hiking trails, over 100 backcountry huts and lodges and 40 major downhill ski areas (Fredman et al, 2001).

Both in terms of number of ski resorts and skier visits, Sweden is among the top ten ski nations in the world and downhill skiing is the major tourist activity in the Swedish mountain region. For the season 2004/05, the total 


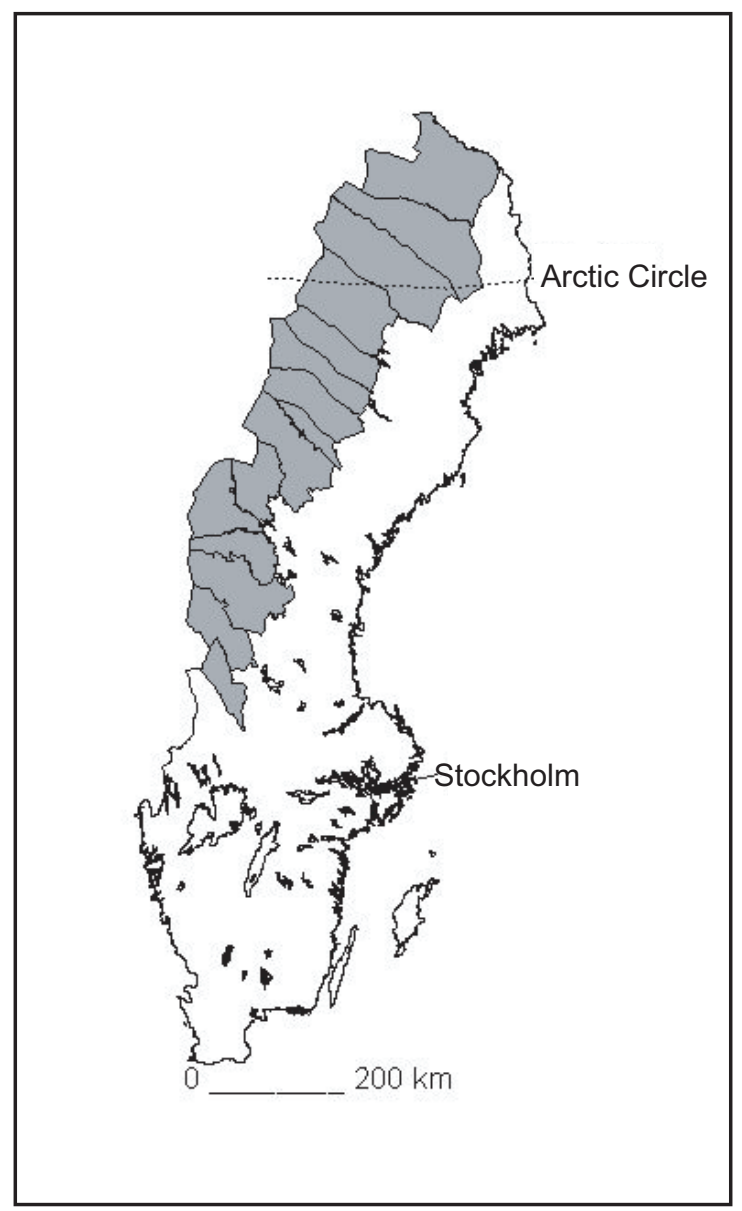

Figure 1. Sweden and the mountain region (shaded area).

turnover for the Swedish ski industry was estimated at SEK900 million (approximately $€ 100$ million). The ski industry has followed the same general trend as elsewhere in the world of an increased concentration with fewer, but larger, operators. The current market is primarily domestic (about $90 \%$ of the skiers are from Sweden), but efforts are being made to increase the international share outside of the Nordic countries (Flagestad and Hope, 2001). Neither snowmobiling nor backpacking is organized as an economic activity in the same way as downhill skiing. These two activities are much more controlled by means of clubs and non-profit organizations, and economic figures equivalent to downhill skiing are not available.

Like many places elsewhere in the world, tourism is seen as an effective way to support the rural communities also in the north of Sweden. This is primarily the result of the notion that tourism has the potential to absorb workforce formerly occupied in other, labour-declining sectors. However, a recent study by Lundmark (2005) shows that the positive effect of tourism on population and economic development in the Swedish mountain municipalities is small, 
although one potentially significant factor for a positive employment change is proximity to ski lifts (Lundmark et al, 2006). Considerable efforts have also recently been directed to promote international skiing, as well as year-round tourism, in the north of Sweden.

\section{Data collection and measurement}

Data for this study were collected using mailed questionnaires distributed to four groups of mountain visitors (downhill skiers, backpackers, snowmobilers and 'general' visitors) identified in a preceding national telephone screener survey. The screener survey included 3,506 completed telephone interviews using a random sample of Swedish households living outside the mountain region (Figure 1). The individual in the household, aged between 15 and 70 years old, who had the most recent birthday was chosen as the interviewee. The questions asked addressed visits to the Swedish mountain region in the past five years.

The follow-up mail survey contained a general section that applied to all. Respondents who said in the telephone interview that their most recent trip was for downhill skiing received a second section in the questionnaire focusing on downhill skiing. Those who reported their most recent trip was for backpacking received a second section devoted to this activity, and similarly for snowmobilers. Respondents who did not participate in either skiing, backpacking or snowmobiling during their trip are referred to as general visitors. The questionnaires were mailed out in November 2000. A first reminder was sent out in December 2000, a second reminder card was also sent out in December, and a third reminder, including a new questionnaire, was distributed in January 2001. In February 2001, a telephone reminder was directed to backpackers living outside the mountain region and every third downhill skier who had failed to return a questionnaire, in order to increase response rates among these groups. As only a small number of backpackers were identified in the telephone screener, their responses to the follow-up mailed survey became of particular importance so they were, therefore, provided with an incentive (a small backpack). Table 1 summarizes the sample data and response rates for the different visitor categories.

Expenditure data were collected in a separate section in the mailed questionnaire, including expenditures both at and outside the mountain region (Figure 1). Expenditures at the destination included: 'accommodation', 'ski pass', 'fishing licence', 'local transportation', 'ski school', 'courses', 'guiding',

Table 1. Sample data and response rates of the mailed questionnaires.

Downhill skiers Backpackers Snowmobilers General visitors

Number of valid

$\begin{array}{lllll}\text { surveys returned } & 323 & 93 & 66 & 241\end{array}$

$\begin{array}{lllll}\text { Response rate }(\%) & 48.7 & 89.8 & 52.7 & 56.6\end{array}$ 
Table 2. Average expenditures (in Swedish kronor, SEK) for skiers, backpackers, snowmobilers and general visitors to the Swedish mountain region.

\begin{tabular}{|c|c|c|c|c|c|}
\hline & Item & $\begin{array}{l}\text { Skiers } \\
(n=270)\end{array}$ & $\begin{array}{c}\text { Backpackers } \\
\quad(n=88)\end{array}$ & $\begin{array}{l}\text { Snowmobilers } \\
\quad(n=62)\end{array}$ & $\begin{array}{l}\text { General visitors } \\
\quad(n=202)\end{array}$ \\
\hline 1 & Accommodation & $\begin{array}{c}971 \\
(824-1,118)\end{array}$ & $\begin{array}{c}351 \\
(227-474)\end{array}$ & $\begin{array}{c}556 \\
(374-739)\end{array}$ & $\begin{array}{c}822 \\
(665-980)\end{array}$ \\
\hline 2 & $\begin{array}{l}\text { Ski pass; fishing } \\
\text { licence, local } \\
\text { transportation; } \\
\text { ski school, courses, } \\
\text { guiding, etc }\end{array}$ & $\begin{array}{c}728 \\
(629-826)\end{array}$ & $\begin{array}{c}91 \\
(44-137)\end{array}$ & $\begin{array}{c}63 \\
(37-89)\end{array}$ & $\begin{array}{c}97 \\
(55-139)\end{array}$ \\
\hline 3 & Amusement & $\begin{array}{c}274 \\
(205-344)\end{array}$ & $\begin{array}{c}36 \\
(6-65)\end{array}$ & $\begin{array}{c}104 \\
(17-191)\end{array}$ & $\begin{array}{c}78 \\
(44-112)\end{array}$ \\
\hline 4 & Restaurants, groceries & s $\begin{array}{c}774 \\
(691-856)\end{array}$ & $\begin{array}{c}342 \\
(266-417)\end{array}$ & $\begin{array}{c}681 \\
(519-844)\end{array}$ & $\begin{array}{c}628 \\
(525-731)\end{array}$ \\
\hline 5 & Equipment rentals & $\begin{array}{c}98 \\
(68-128)\end{array}$ & $\begin{array}{c}8 \\
(0-17)\end{array}$ & $\begin{array}{c}181 \\
(94-268)\end{array}$ & $\begin{array}{c}45 \\
(16-75)\end{array}$ \\
\hline 6 & $\begin{array}{l}\text { Petrol and oil; } \\
\text { equipment, } \\
\text { clothing, souvenirs } \\
\text { and gifts }\end{array}$ & $\begin{array}{c}146 \\
(95-198)\end{array}$ & $\begin{array}{c}143 \\
(88-198)\end{array}$ & $\begin{array}{c}459 \\
(221-696)\end{array}$ & $\begin{array}{c}234 \\
(104-365)\end{array}$ \\
\hline 7 & $\begin{array}{l}\text { Total expenditures at } \\
\text { the destination }\end{array}$ & $\begin{array}{c}2,991 \\
(2,699-3,283)\end{array}$ & $\begin{array}{c}969 \\
(748-1,190)\end{array}$ & $\begin{array}{c}2,045 \\
(1,563-2,527)\end{array}$ & $\begin{array}{c}1,904 \\
(1,605-2,205)\end{array}$ \\
\hline 8 & $\begin{array}{l}\text { Equipment rentals; } \\
\text { groceries; petrol } \\
\text { and oil outside the } \\
\text { destination }\end{array}$ & $\begin{array}{c}269 \\
(214-323)\end{array}$ & $\begin{array}{c}296 \\
(237-354)\end{array}$ & $\begin{array}{c}407 \\
(278-536)\end{array}$ & $\begin{array}{c}287 \\
(205-370)\end{array}$ \\
\hline 9 & $\begin{array}{l}\text { Transport and } \\
\text { accommodation } \\
\text { to/from the destinati }\end{array}$ & $\begin{array}{l}639 \\
(554-723) \\
\text { tion }\end{array}$ & $\begin{array}{c}1,031 \\
(855-1,208)\end{array}$ & $\begin{array}{c}684 \\
(549-819)\end{array}$ & $\begin{array}{c}1,010 \\
(819-1,201)\end{array}$ \\
\hline 10 & $\begin{array}{l}\text { Total expenditures out- } \\
\text { side the destination }\end{array}$ & $\begin{array}{c}908 \\
(794-1,022)\end{array}$ & $\begin{array}{c}1,327 \\
(1,129-1,525)\end{array}$ & $\begin{array}{c}1,091 \\
(897-1,285)\end{array}$ & $\begin{array}{c}1,297 \\
(1,088-1,508)\end{array}$ \\
\hline 11 & $\begin{array}{l}\text { Proportion of } \\
\text { expenditures at } \\
\text { the destination }\end{array}$ & $77 \%$ & $42 \%$ & $65 \%$ & $59 \%$ \\
\hline 12 & $\begin{array}{l}\text { Unspecified } \\
\text { expenditures }\end{array}$ & $\begin{array}{c}257 \\
(180-334)\end{array}$ & $\begin{array}{c}347 \\
(214-480)\end{array}$ & $\begin{array}{c}175 \\
(89-263)\end{array}$ & $\begin{array}{c}504 \\
(344-665)\end{array}$ \\
\hline 13 & Total expenditures & $\begin{array}{c}4,156 \\
(3,786-4,527)\end{array}$ & $\begin{array}{c}2,643 \\
(2,243-3,043)\end{array}$ & $\begin{array}{c}3,312 \\
(2,728-3,895)\end{array}$ & $\begin{array}{c}3,708 \\
(3,243-4,172)\end{array}$ \\
\hline
\end{tabular}

Note: Figures in parentheses are the $95 \%$ confidence interval for the mean.

'amusement', 'restaurants and groceries', 'equipment rentals', 'petrol and oil' and 'equipment, clothing, souvenirs and gifts' (Table 2, items 1-6). Expenditures outside the destination included: 'equipment rentals', 'groceries', 'petrol and oil' and 'transport and accommodation to/from the destination' (Table 2, items 8 and 9).

The framing of the expenditure question differed slightly between the different activity groups as, for example, a ski pass was only applicable to downhill skiers and 'petrol and oil' only to snowmobilers. Expenditures were 
reported in Swedish kronor $(€ 1 \approx$ SEK9) on an individual basis; that is, each respondent was asked to report his or her personal expenditures, including his or her share of common (group, family, etc) expenditures and expenditures paid by someone else. For example, if travel to the mountains was by car in a group of four, the respondent was asked to report the total travel cost of the car divided by four. Missing values in the expenditure questions are treated as zero if the respondent reports expenditure for at least one item. If all items have missing values, the entire question is treated as missing. When expenditures are analysed on a daily basis, this includes days for the entire trip, not only at the destination.

Given the five-year time frame of the study, there is a possibility of recall bias in the expenditure estimates (Rylander et al, 1995), which should be kept in mind when reading the results. Since this study is part of a larger project on mountain tourism, the choice of time frame is pre-determined and, as long as a possible bias is equal across the study groups, between-group comparisons should still be valid. A simple test of the difference in average total expenditures between respondents who visited the mountains during the years 1999/ 2000 compared to those who reported expenditure data for an earlier trip show no statistically significant differences. However, looking at the individual expenditure items (Table 2), significant differences are identified for item 2 (ski pass, fishing licence, local transportation, ski school, courses, guiding, etc) and item 8 (equipment rentals, groceries, petrol and oil outside the destination), indicating a possible recall bias (that is, underestimation of expenditures in earlier periods). It is not likely that these differences are explained by changes in relative prices since the consumer price index in Sweden increased by only $1.8 \%$ between 1996 and 2000. Consequently, figures have not been adjusted to correct for inflation during the study period.

Expenditure data for all four groups of mountain visitors (skiers, backpackers, snowmobilers and general visitors) are presented in Table 2 . The most obvious difference is perhaps the high expenditure levels on several items for downhill skiers compared to the other groups. Average total expenditures at the destination are three times higher for skiers compared to backpackers. A tent is not normally used when skiing and accommodation at ski resorts is often of a considerably higher standard than the more remote lodges and cabins used primarily by snowmobilers and hikers. While downhill skiing is associated with expensive equipment which some may prefer to rent, this is even more the case for snowmobilers. As snowmobiling has increased in popularity, the number of snowmobile rentals in the mountain region has also increased considerably. This trend is obviously mirrored in the results. Driving a snowmobile is also associated with a considerably larger demand for petrol and oil compared to the other activities.

Expenditures outside the mountain region follow a slightly different pattern compared to those at the destination. While equipment rentals, groceries, petrol and oil (to be used at the destination, but purchased outside) is high for snowmobilers, Table 2 shows that backpackers and general visitors have, on average, significantly higher expenditures for transport to/from the mountain region. For this item, backpackers spend on average 60\% more than skiers. By dividing the total expenditures at the destination (item 7) with the total expenditures both at and outside the destination (items $7+10$ ), the proportion 
of expenditures spent at the destination is obtained for each group. These figures clearly show that downhill skiers spend most of their total trip expenditures at the final destination, while backpackers, in contrast, allocate more than half their expenditures outside the mountain region. Unspecified expenditures are the difference between the sum of all specified items in Table 2 (items 7 and 10) and the total expenditures of the trip (which were asked for in a separate question). It has not been possible to allocate these unspecified expenditures to the 'at' or 'outside' destination categories.

\section{Modelling visitor expenditures}

The next step is to model visitor expenditures in order to test the statistical significance between different visitor types while also looking for other determinants. Because of non-normality of the distributions, and to alleviate the potential for heteroskedasticity, $\log -$ linear regression functions are used in the analyses. Both linear and semi-log models were tried, but the log-linear model proved the best fit. One important feature of the log-linear model is that the slope coefficient measures the elasticity of the dependent variable with respect to the independent variables, and the model assumes that the elasticity coefficient between the two variables is constant (Greene, 1997). The first model used considers expenditures at the destination

$$
\begin{aligned}
\ln \left(Y_{i}\right)= & \alpha+\beta_{1} \ln (\text { dad })_{i}+\beta_{2} \ln (i n c)_{i}+\beta_{3} D S_{i}+\beta_{4} B P_{i}+\beta_{5} S M_{i} \\
& +\beta_{6} G E_{i}+\beta_{7} S T_{i}+\beta_{8} R E_{i}+\beta_{9} O T_{i}+\beta_{10} C A_{i}+\beta_{11} S A_{i}+\varepsilon_{i}
\end{aligned}
$$

where $Y_{i}$ is the amount of total individual expenditures and $\varepsilon_{i}$ an error term. Independent variables included in continuous format are number of days at the destination and household income, which accordingly are log-transformed. Dummy variables included control for downhill skiing, backpacking, snowmobiling, gender, occupation, if an organization or employer organized the trip, if commercial accommodation was used and if the main leisure activity undertaken at the destination was very important for the total experience at the destination. The second model used considers expenditures outside the destination

$$
\begin{aligned}
\ln \left(Y_{i}\right)= & \alpha+\beta_{1} \ln (i n c)_{i}+\beta_{2} D S_{i}+\beta_{3} B P_{i}+\beta_{4} S M_{i}+\beta_{5} G E_{i}+\beta_{6} S T_{i} \\
& +\beta_{7} R E_{i}+\beta_{8} O T_{i}+\beta_{9} T R_{i}+\beta_{10} A T_{i}+\beta_{11} S S_{i}+\beta_{12} S A_{i}+\varepsilon_{i}
\end{aligned}
$$

where $Y_{i}$ is the amount of total individual expenditures and $\varepsilon_{i}$ an error term. Here, household income is log-transformed, while dummy variables control for downhill skiing, backpacking, snowmobiling, gender, occupation, if the trip is organized by an organization or the employer, if a train is used, if air travel is used, if the respondent lives in southern Sweden, and if the main leisure activity undertaken at the destination is very important for the total experience at the destination.

The definitions of the independent variables are as follows:

$\alpha \quad=$ constant

$\ln (d a d)=$ natural logarithm of number of days at the destination 
$\ln ($ inc $)=$ natural logarithm of household income

$D S \quad=1$ if downhill skier; 0 otherwise

$B P \quad=1$ if backpacker; 0 otherwise

$S M \quad=1$ if snowmobiler; 0 otherwise

$G E \quad=1$ if female, 2 if male

$S T=1$ if occupation is student; 0 otherwise

$R E \quad=1$ if occupation is retired; 0 otherwise

$O T=1$ if conducted trip arranged by organization or employer; 0 otherwise

$C A=1$ if commercial accommodation was used at the destination; 0 otherwise

$T R=1$ if train was used to travel to the destination; 0 otherwise

$A T \quad=1$ if air travel was used to travel to the destination; 0 otherwise

SS $\quad=1$ if the respondent permanently lives in southern Sweden; 0 otherwise

$S A \quad=1$ if the main leisure activity undertaken at the destination was very important for total experience at the destination; 0 otherwise

In both models, the 'general visitors' serve as the reference category for the activity groups. If transportation was not by train or air, the reference category was by car/bus. Respondents living in southern Sweden will have a longer travel distance to get to the mountains and are defined as individuals living in the region of Götaland (based on postal codes). The last variable is a measure of how important the activity is for the total experience at the destination (on a four-point scale), which will show how visitor spending is related to activities per se.

\section{Results}

Table 3 features the regression models of visitor expenditures both at and outside the destination (mountain region). Looking at model 1, expenditures at the destination are positively associated with both the length of stay and household income. A $1 \%$ increase in the length of stay at the destination implies a $0.51 \%$ increase in visitor expenditures, and a $1 \%$ increase in income is associated with a $0.25 \%$ increase in expenditures (note that the structure of regression equations and the use of intercept dummies assumes that the coefficient on income and on days at destination is the same for all visitor groups). The positive relationship between visitor expenditures and income implies that visits to the Swedish mountains are 'normal good'; that is, more is demanded the higher the income. The results also show that downhill skiers spend more and backpackers less, which corresponds to the results in Table 2. Both students and retired people are sometimes targeted as special segments in marketing efforts and Table 3 indicates that students have lower expenditures compared to other social groups. Those who attended on an organized trip also had lower expenditures compared to those who did not. One reason for this could be that organized trips are a way to economize, but another explanation could be that respondents did not fully report expenditures paid by, for example, their employer. On average, visitors staying in commercial accommodation have higher expenditures compared to those staying with relatives/friends or in their own tent/caravan. The significance of the activity (that is, individuals who considered the main 
Table 3. Determinants of visitor expenditures at and outside the destination.

\begin{tabular}{|c|c|c|c|}
\hline & Independent variable & $\begin{array}{c}\text { Model 1: } \\
\text { Expenditures at } \\
\text { destination } \\
\text { Coefficient }(t \text {-ratio) }\end{array}$ & $\begin{array}{c}\text { Model 2: } \\
\text { Expenditures outside } \\
\text { destination } \\
\text { Coefficient }(t \text {-ratio })\end{array}$ \\
\hline$\alpha$ & Constant & $\begin{array}{c}2.769 * * * \\
(3.32)\end{array}$ & $\begin{array}{c}4.212 * * * \\
(6.57)\end{array}$ \\
\hline $\operatorname{Ln}(\mathrm{dad})$ & Days at destination & $\begin{array}{c}0.508 * * * \\
(6.01)\end{array}$ & \\
\hline Ln(inc) & Household income & $\begin{array}{c}0.246 * * * \\
(3.70)\end{array}$ & $\begin{array}{c}0.178 * * \\
(3.41)\end{array}$ \\
\hline DS & Downhill skier & $\begin{array}{c}0.591 * * * \\
(5.96)\end{array}$ & $\begin{array}{c}-0.261 * * \\
(-3.50)\end{array}$ \\
\hline BP & Backpacker & $\begin{array}{c}-0.412 * * \\
(-2.92)\end{array}$ & $\begin{array}{l}-0.092 \\
(-0.84)\end{array}$ \\
\hline SM & Snowmobiler & $\begin{array}{l}0.187 \\
(1.23)\end{array}$ & $\begin{array}{l}-0.037 \\
(-0.31)\end{array}$ \\
\hline GE & Gender & $\begin{array}{l}0.125 \\
(1.49)\end{array}$ & $\begin{array}{c}0.182 * * \\
(2.81)\end{array}$ \\
\hline ST & Student & $\begin{array}{c}-0.304^{*} \\
(-2.34)\end{array}$ & $\begin{array}{c}-0.295 * * \\
(-2.89)\end{array}$ \\
\hline $\mathrm{RE}$ & Retired & $\begin{array}{l}0.054 \\
(0.33)\end{array}$ & $\begin{array}{l}0.149 \\
(1.19)\end{array}$ \\
\hline OT & Organized trip & $\begin{array}{c}-0.376 * * \\
(-3.02)\end{array}$ & $\begin{array}{c}-0.405 * * * \\
(-4.18)\end{array}$ \\
\hline CA & Commercial accommodation & $\begin{array}{c}0.435 * * * \\
(4.79)\end{array}$ & \\
\hline TR & Train & & $\begin{array}{c}0.531 * * * \\
\quad(4.64)\end{array}$ \\
\hline AT & Air-travel & & $\begin{array}{c}1.090 * * * \\
(6.92)\end{array}$ \\
\hline SS & Southern Sweden & & $\begin{array}{c}0.256 * * * \\
(3.78)\end{array}$ \\
\hline SA & Significance of activity & $\begin{array}{l}0.142 \\
(1.69)\end{array}$ & $\begin{array}{c}0.154^{*} \\
(2.36)\end{array}$ \\
\hline \multicolumn{2}{|c|}{$\begin{array}{l}R^{2} \\
\text { Adj. } R^{2} \\
\text { Model } F \text {-value }\end{array}$} & $\begin{array}{c}33.8 \\
32.1 \\
20.497 \\
(p<0.000)\end{array}$ & $\begin{array}{c}25.5 \\
23.8 \\
14.662 \\
(p<0.000)\end{array}$ \\
\hline
\end{tabular}

Note: $t$-ratios are shown in parentheses. *Significant at 0.05 level; **significant at 0.01 level; $* * *$ significant at 0.001 level or better.

leisure activity undertaken at the destination as 'very important' for the total experience) had no effect on expenditures at the destination.

Looking at the regression of visitor expenditures outside the destination (Table 3, model 2), there are several results parallel to those at the destination. Income is positively associated with expenditure level, while students and participants on organized trips have, on average, lower expenditures. There are, 
however, some notable differences between the two models. Male visitors spend more money outside the mountain region compared to female visitors, and downhill skiers spend less than general mountain visitors. Travel by train or air is associated with higher expenditures outside the final destination in the mountain region compared to travel by car/bus. Respondents living in the south of Sweden have, on average, higher expenditures compared to individuals living further north (closer to the mountain region), probably because a long travel distance often implies air travel or long-distance trains. Some covariation is present between trains and living in the south of Sweden (Pearson correlation $=0.135$ ), while no such relationship exists for air travel. Model 2 also shows that individuals who considered the main leisure activity undertaken at the destination as 'very important' for the total experience did spend more money to get to the mountains compared to those who did not.

\section{Values beyond expenditures}

While basically all travel involves consumption of market goods and services (for example, fuel, food, lodging, etc) associated with out-of-pocket expenditures, most nature-based tourism also involves the 'consumption' of nonmarket values such as beautiful scenery, wildlife, clean air or public trails. For example, a mountain tourist may combine travel, equipment and food supplies with beautiful scenery, a waterfall and wildlife to 'produce' a backpacking trip. In this case, travel, equipment and food are market goods that are priced where demand equals supply, while in most cases the 'consumption' of beautiful scenery, a waterfall or wildlife is free of charge but nevertheless represents a significant part of the total outdoor experience. Consequently, the true value of the nature-based tourism product is often more than simply the out-of-pocket expenditures paid to participate.

The value placed above and beyond the actual expenses incurred to participate in a trip is considered a consumer surplus - which is a net benefit relevant for both market and non-market goods (for example, Peterson et al, 1992; Loomis and Walsh, 1997). Consumer surplus can be measured as the difference between total WTP and total expenditures, where WTP for a given quantity of a product is measured by the area under the market demand function up to that quantity. WTP reflects total utility derived by an individual from consuming the product, while total expenditures represent the disutility from consumption.

As an illustration of the values beyond out-of-pocket expenditures involved in Swedish mountain tourism, we can take a look at the WTP among the different visitor categories included in the current study. Respondents were asked, in an open-ended question format, to think of the trip they had done and report the maximum amount they would be willing to pay for it:

Think about the trip reported in the previous question. What is the maximum amount you are willing to pay for this trip? (Report the total amount you would be willing to pay for the trip before you would decide not to undertake it.) I would be willing to pay a maximum of SEK. 
Table 4. Willingness to pay and consumer surplus (in Swedish kronor, SEK) among skiers, backpackers, snowmobilers and general visitors to the Swedish mountain region.

\begin{tabular}{lcccc}
\hline Item & $\begin{array}{c}\text { Skiers } \\
(n=241)\end{array}$ & $\begin{array}{c}\text { Backpackers } \\
(n=85)\end{array}$ & $\begin{array}{c}\text { Snowmobilers } \\
(n=58)\end{array}$ & $\begin{array}{c}\text { General visitors } \\
(n=177)\end{array}$ \\
Willingness to pay & 4,611 & 3,514 & & 3,719 \\
Consumer surplus & $(4,178-5,042)$ & $(2,876-4,153)$ & $(3,136-4,301)$ & $(3,458-4,485$ \\
& 293 & 896 & 456 & 222 \\
& $(19-567)$ & $(483-1,309)$ & $(77-836)$ & $(0-533)$ \\
\hline
\end{tabular}

Note: Figures in parentheses are the $95 \%$ confidence interval for the mean.

This represents a hypothetical monetary measure of the value of the trip that also captures non-market commodities. For a presentation of contingent valuation and other non-market valuation methods, see for example, Mitchell and Carson (1989), Bjornstad and Kahn (1996) and Garrod and Willis (1999). Table 4 features the WTP and the consumer surplus (the difference between WTP and total expenditures for those respondents who gave a valid answer to the WTP question) for each category of mountain visitor studied. More specifically, this simple analysis shows that skiers have the highest WTP, but they also have the highest economic expenditures - so their consumer surplus is relatively small. In contrast, backpackers have the lowest WTP, but they also have the lowest expenditures - so their consumer surplus is large. Relative to total expenditures, the consumer surplus is $6 \%$ for general visitors, $7 \%$ for skiers, $14 \%$ for snowmobilers and $34 \%$ for backpackers. Given the statistical inference, one should interpret this result with some caution, but it gives an indication that backpackers retain more of the economic benefits of consumer surplus while more economic activity is generated among the other groups. Looking at this from a different perspective, the tourism industry may try to develop backpacking services that, to some extent, can capitalize on the surpluses identified here. For example, a backpacking trip sold as a package tour including a guide will probably capture some of the non-market values since a guide will take the customer to the most scenic trails, the best camping grounds and will know where to spot wildlife (at least this is what the customer believes and pays for).

\section{Concluding remarks}

The results presented in this study illustrate variations in expenditure patterns among different categories of mountain visitors and identifies a number of significant determinants both at and outside the destination. These results do have several implications for future development of tourism in the Swedish mountain region that should also be applicable to many other mountain regions. Visitor expenditures are a measure of the direct economic impact to a region or country from tourism. This includes the primary tourism sectors such as 
accommodation, restaurants, amusements, transport, etc. Following the primary sectors, tourism also involves several indirect and induced economic effects, such as re-spending by the tourism industry and households on other sectors of the economy (for example, Lindberg, 2001; Ryan, 2003). While estimates of such secondary economic effects are beyond the scope of this paper, one should observe that the final regional stimulus of an economic activity will equal the direct expenditures times the multiplier, and the size of the multiplier will vary according to the expenditure patterns of the industry that receives that initial injection of money. Further research into the secondary economic effects needs to be carried out before one can claim that one type of visitor generates greater regional economic benefits than another.

Among the groups studied in this paper, downhill skiers are identified as those having the largest direct impact on the local economy. Their spending is, on average, three times higher than that of backpackers and $50 \%$ higher than that of snowmobilers. Various services (for example, ski pass, ski school, guiding, courses, local transportation, fishing licences, etc) are identified as the economic drivers in this group. The average skier spends eight times as much money on such services compared to the average backpacker and eleven times more money than the average snowmobiler. Without the possibility of charging people to travel up the mountains, downhill skiing would not have been as successful an industry as recent developments have shown. Being in a ski resort is also associated with social activities. Fredman and Heberlein (2005) found that downhill skiing has a strong 'social component' and that skiers in the mountains are more likely to have family and friends who ski compared to skiers elsewhere. This is probably one explanation why we find skiers spending significantly more on amusement that the other groups. There are, however, some limitations to skiing - the most obvious being dependence on snow, which limits the season to less than half a year and is sensitive to future climate change. As a consequence, efforts are being made to develop summer tourism in the region (Flagestad and Hope, 2001). Yet another limitation could be the maturation of the domestic ski market (Fredman and Heberlein, 2003) and, in order to increase the volume of skiers, the industry probably needs to look for customers abroad. Then, perhaps, an alternative strategy is to develop backpacking services that, to some extent, can capture the consumer surplus identified among this group.

This study also replicates the finding that duration of stay has a positive effect on visitor spending (cf Cannon and Ford, 2002; Downward and Lumsdon, 2003). The tourism industry should, therefore, benefit economically from visitors who stay longer. However, since the relative increase in spending is less than the relative increase in duration of stay, the industry would do even better by filling an empty bed with a new visitor rather than extending the length of stay of current visitors. The regression analysis also shows that experiences from the main activity have no effect on expenditures at the destination, while they are positively associated with off-destination expenditures (most of which are travel expenses). People are willing to pay more to get to playgrounds of better quality but, once there, experiences of the main activity do not determine expenditure levels. This result should have some obvious implications for those developing travel services directed at specific activity groups. 


\section{References}

Agarwal, V.B., and Yochum, G.R. (1999), 'Tourist spending and race of visitors', Journal of Travel Research, Vol 38, pp 173-176.

Bjornstad, D.J., and Kahn, J.R. (1996), The Contingent Valuation of Environmental Resources, Edward Elgar, Cheltenham.

Buckley, R.V., Pickering, C.M., and Warnken, J. (2000), 'Environmental management for alpine tourism and resorts in Australia', in Godde, P.M., Price, M.F., and Zimmermann, F.M., eds, Tourism and Development in Mountain Regions, CABI Publishing, Wallingford.

Cannon, T.F., and Ford, J. (2002), 'Relationship of demographic and trip characteristics to visitor spending: an analysis of sports travel visitors across time', Tourism Economics, Vol 8, No 3, pp 263-271.

Cordell, H.K. (2004), Outdoor Recreation for 21st Century America. A Report to the Nation: The National Survey on Recreation and the Environment, Venture Publishing, State College, PA.

Díaz-Pérez, F.M., Bethencourt-Cejas, M., and Álvarez-Gonzáles, J.A. (2005), 'The segmentation of Canary Island tourism markets by expenditure: implications for tourism policy', Tourism Management, Vol 26, No 6, pp 961-964.

Downward, P., and Lumsdon, L. (2000), 'The demand for day-visits: an analysis of visitor spending', Tourism Economics, Vol 6, No 3, pp 251-261.

Downward, P., and Lumsdon, L. (2003), 'Beyond the demand for day-visits: an analysis of visitor spending', Tourism Economics, Vol 9, No 1, pp 67-76.

Downward, P., and Lumsdon, L. (2004), 'Tourism transport and visitor spending: a study in the North York Moors National Park', Journal of Travel Research, Vol 42, pp 415-420.

Fish, M., and Waggle, D. (1996), 'Current income versus total expenditure measures in regression models of vacation and pleasure travel', Journal of Travel Research, Fall, pp 70-74.

Flagestad, A., and Hope, C.A. (2001), 'Scandinavian winter: antecedents, concepts and empirical observations underlying a destination umbrella branding model', Tourism Review, Vol 56, pp 512.

Framke, W. (2002), 'The destination as a concept: a discussion of the business-related perspective versus the socio-cultural approach in tourism theory', Scandinavian Journal of Hospitality and Tourism, Vol 2, No 2, pp 92-108.

Fredman, P., and Heberlein, T.A. (2003), 'Changes in skiing and snowmobiling in Swedish mountains', Annals of Tourism Research, Vol 30, No 2, pp 485-488.

Fredman, P., and Heberlein, T. (2005), 'Visits to the Swedish mountains: constraints and motivations', Scandinavian Journal of Hospitality and Tourism, Vol 5, No 3, pp 177-192.

Fredman, P., Emmelin, L., Heberlein, T.A., and Vuorio, T. (2001), 'Tourism in the Swedish mountain region', in Sahlberg, B., ed, Going North, Report R 2001:6, European Tourism Research Institute, Östersund.

Garrod, G., and Willis, K.G. (1999), Economic Valuation of the Environment. Methods and Case Studies, Edward Elgar Publishing, Massachusetts, MA.

Godde, P.M., Price, M.F., and Zimmermann, F.M. (2000), Tourism and Development in Mountain Regions, CABI Publishing, Wallingford.

Greene, W.H. (1997), Econometric Analysis, Third edition, Prentice Hall, Upper Saddle River, NJ.

Heberlein, T.A., Fredman, P., and Vuorio, T. (2002), 'Current tourism patterns in the Swedish mountain region', Mountain Research and Development, Vol 22, No 2, pp 142-149.

Hudson, S. (2003), Sport and Adventure Tourism, Haworth Hospitality Press, New York.

Klenosky, D.B. (2002), 'The "pull” of tourism destinations: a means-end investigation', Journal of Travel Research, Vol 40, pp 385-395.

Lee, C.-K., Var, T., and Blaine, T.W. (1996), 'Determinants of inbound tourism expenditures', Annals of Tourism Research, Vol 23, No 3, pp 527-542.

Lindberg, K. (2001), 'Economic impacts', in Weaver, D.B., ed, The Encyclopedia of Ecotourism, CABI Publishing, Wallingford.

Loomis, J.B., and Walsh, R.G. (1997), Recreation Economic Decisions. Comparing Benefits and Costs, Venture Publishing, Pennsylvania, PA.

Lundmark, L. (2005), 'Economic restructuring into tourism in the Swedish mountain range', Scandinavian Journal of Tourism and Hospitality, Vol 5, No 1, pp 23-45.

Lundmark, L., Fredman, P., and Sandell, K. (2006), 'The role of National Parks and protected areas for labour market restructuring: from forest sector employment for tourism, forestry and forest sector employment in Swedish mountain municipalities', in Lundmark, L., ed, Restructuring and 
Employment Change in Sparsely Populated Areas: Examples from Northern Sweden and Finland, Department of Social and Economic Geography, University of Umeå, GERUM, 2006:2.

Mak, J. (2004), Tourism and the Economy. Understanding the Economics of Tourism, University of Hawai' $\mathrm{i}$ Press, Honolulu, HI.

Mitchell, R.C., and Carson, R.T. (1989), Using Surveys to Value Public Goods. The Contingent Valuation Method, Resources for the Future, Washington, DC.

Mok, C., and Iverson, T.J. (2000), 'Expenditure-based segmentation: Taiwanese tourists to Guam', Tourism Management, Vol 21, pp 299-305.

Nogawa, H., Yamaguchi, Y., and Yumiko, H. (1996), 'An empirical research study on Japanese sport tourism in sport-for-all events: case studies of a single night event and a multiple night event', Journal of Travel Research, Vol 35, No 2, pp 46-54.

Oppermann, M. (2000), 'Tourism destination loyalty', Journal of Travel Research, Vol 39, pp 78-84.

Peterson, G.L., Swanson, C.S., McCollum, D.W., and Thomas, M.H. (1992), Valuing Wildlife Resources in Alaska, Westview Press, Boulder, CO.

Regan, T.H., and Damonte, T. (1999), 'A geoeconomic approach to South Carolina NASCAR markets', Public Administration Quarterly, Vol 23, No 3, pp 295-312.

Ryan, C. (2003), Recreational Tourism. Demands and Impacts, Channel View Publications, Clevedon.

Rylander, R.G., Propst, D.B., and McMurtry, T.R. (1995), 'Non-response and recall biases in a survey of traveler spending', Journal of Travel Research, Vol 33, No 4, pp 39-45.

Suh, Y.K., and McAvoy, L. (2005), 'Preferences and trip expenditures - a conjoint analysis of visitors to Seoul, Korea', Tourism Management, Vol 26, pp 325-333.

Taylor, D.T., Fletcher, R.R., and Clabaugh, T. (1993), 'A comparison of characteristics, regional expenditures, and economic impact of visitors to historical sites with other recreational visitors', Journal of Travel Research, Summer, pp 30-35.

Teigland, J. (2000), Nordmenns friluftsliv og naturopplevelser. Et faktagrunnlag fra en panelstudie av langtidsendringer 1986-1999, VF-rapport 7/2000, Western Norway Research Institute, Sogndal.

Thomson, D.B.A., Price, M.F., and Galbraith, C.A. (2005), Mountains of Northern Europe. Conservation, Management, People and Nature, Scottish Natural Heritage, Edinburgh.

Uybers, T.H. (2003), 'Modelling short break holiday destination choices', Tourism Economics, Vol 9, No 4, pp 389-405.

Weiermair, K., Peters, M., and Schipflinger, M. (1996), Alpine Tourism. Sustainability: Reconsidered and Redesigned, Proceedings of the International Conference at the University of Innsbruck, May 1996. ITS- Series: Studies in Tourism and Service Industry. Series 3: Tourism Development. 